\title{
Reducing carbon emission in construction base on project life cycle (PLC)
}

\author{
Mochamad Agung Wibowo ${ }^{1, *}$, Subrata Aditama K. A. Uda ${ }^{2}$, and Zhabrinna ${ }^{3}$ \\ ${ }^{1}$ Lecturer Department of Civil Engineering, Faculty of Engineering, Diponegoro University, Jl. Prof \\ Soedarto, Tembalang, Semarang, Indonesia \\ ${ }^{2}$ Students Department, Study Program Doctoral of Civil Engineering, Faculty of Engineering \\ Diponegoro University, Semarang, Indonesia \\ ${ }^{3}$ School of Engineering and Physical Science, University of Birmingham, The United Kingdom
}

\begin{abstract}
The construction sector accounts for nearly $40 \%$ of global energy annually where $1 / 3$ of it will produce emissions of $\mathrm{CO} 2$ emitted into the atmosphere [1]. Carbon Emissions (CO2) are a major cause of the greenhouse effect, for example, that which is produced from the combustion process of fossil fuels. Increasing the concentration of greenhouse gases into the atmosphere will lead to rising temperatures trapped in the atmosphere causing global warming. There is a lot of literature on carbon emission (discussions) using multiple analytical approaches, but some are reviewing the Project Life Cycle (PLC) approach. This paper will discuss carbon emission mitigation during the life cycle of a construction project (Project Life Cycle (PLC)). Reduction of carbon emissions can be done during the initiation, design and construction phase of the Project Life Cycle (PLC). This literature study will produce a strategy that can have a significant impact on reducing the amount of carbon occurring in any construction project activity.

Keywords: Construction, Carbon Emission, Project Life Cycle.
\end{abstract}

\section{Introduction}

Global warming and extreme climate change are now a real danger to the rest of the world. This not only brings negative impacts to living things but also brings damage to the survival of the living beings themselves. The average planet surface temperature has increased by about 2.0 degrees Fahrenheit or 1.1 degrees Celsius. High temperature changes are driven largely by increases in carbon dioxide and other man-made emissions into the atmosphere. The year 2016 recorded the hottest rise in global temperatures over the past 10 years with an increase of 0.99 degrees Celsius, due to potential climate change impacts caused by anthropogenic emissions of greenhouse gases and aerosols [2].

The commitment of the Indonesian government to reduce global warming is realized by reducing emissions by $26 \%$ by 2020 . This was then revised in 2015 with the target of reducing emissions to $29 \%$ in 2030 independently. However, if there is support from international cooperation then the target can raise to $41 \%$. This commitment includes

\footnotetext{
* Corresponding author: agungwibowo360@gmail.com
} 
aspects of mitigation and adaptation in the forestry sector, energy including transportation, waste, industrial processes and product use, and agriculture. In the construction sector one of the follow-up commitments is the issuance of Regulation of Minister of Public Works No. 11 of 2012 on National Action Plan of Climate Change Mitigation and Adaptation in 2012-2020 and Ministerial Regulation of PUPR Number 02 / PRT / M / 2015 on Green Building for reduction greenhouse gas (GHG) emissions sourced from buildings. Strategies to reduce emissions should be made in all sectors and all regions. Reduced energy use can be done in several ways, such as energy efficiency. Many countries already have policies to reduce emissions, but more importantly their application.

The construction sector is responsible for the use of $40 \%$ of global energy, $25 \%$ of global water and $40 \%$ of global resources emitted to the atmosphere of $1 / 3$ of the world's GHG emissions, while during the building phase about $60 \%$ of the world's electricity is consumed. The impact of using energy inefficiency will slowly degrade the quality of the environment globally. CO2 emission gas comes from energy released during the life cycle of the building starting from the production stage, construction phase, operational phase, and the demolition phase/the end of the building. Energy consumption produces $\mathrm{CO} 2$, which contributes to greenhouse gas emissions, so that contained energy is considered as an indicator of the overall environmental impact of building materials and systems [3].

Based on data from the Central Bureau of Statistics 2016 the contribution rate of Indonesia's gross domestic product in the construction sector is the highest among ASEAN countries during the last 3 (three) years in which the contribution value of $9.49 \%$ in 2013 , then increased in 2014 by $9.86 \%$ and in 2015 by $10.34 \%$. This increase was higher by an average difference of $0.5 \%$ compared to the Philippines and 5\% to Singapore (Fig 1).

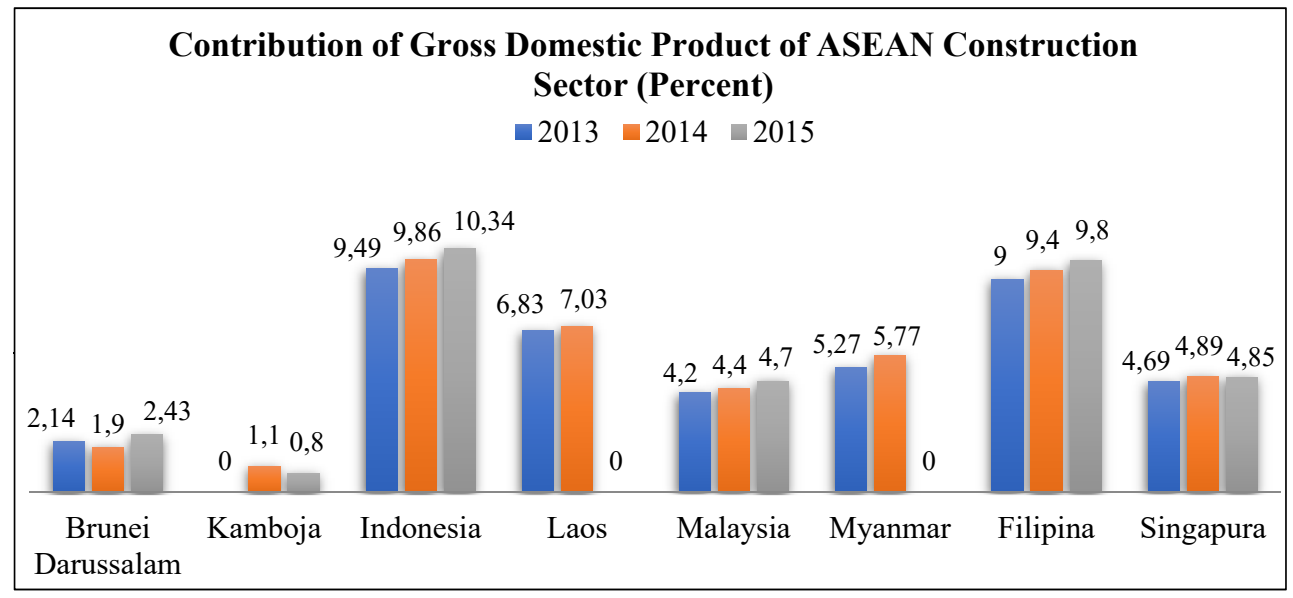

Fig. 1. Contribution of gross domestic product of ASEAN construction sector (Source: Central Bureau of Statistics, 2016)

This shows that the construction industry in Indonesia has a value of profitable investment in line with economic and political stability. However, such investments sometimes also cause losses where if construction activities do not pay attention to environmentally-friendly development rules will result in environmental damage such as the rise in temperature due to greenhouse gases ( $\mathrm{CO} 2$ emissions). The purpose of this study is to explore the most effective way to reduce carbon emissions that occur during the life cycle of projects in the construction sector. 


\section{Literature study}

\subsection{Project life cycle (PLC)}

The project life cycle serves to determine the start and the end of the project activity, to identify the opportunity to be achieved, and to formulate whether a project should be implemented. The project life cycle generally involves some form of technology transfer or required material design, implementation and maintenance design [4]. There are four stages in the construction project life cycle including project initiation or conceptualisation, project planning or design, construction and termination phase, which covers operation and maintenance.

Table 1. Project life cycle.

\begin{tabular}{|l|l|l|l|l|}
\hline & \multicolumn{1}{|c|}{ Phase I } & \multicolumn{1}{c|}{ Phase II } & \multicolumn{1}{c|}{ Phase III } & \multicolumn{1}{c|}{ Phase IV } \\
\cline { 2 - 5 } & \multicolumn{1}{|c|}{ Initiation } & \multicolumn{1}{c|}{ Planning } & \multicolumn{1}{c|}{ Execution } & Termination \\
\hline Hypothesized & Project Mission & Project Mission & Schedule / Plans & Client \\
Dominant & Client & Top & Personnel Technical & Acceptance \\
Critical & Consultation & Management & Tasks & Client \\
Success & & Client & Trouble-Shooting & Consultation \\
Factors & & Consultation & Client Consultation & \\
& & Client & Monitoring and & \\
& & Acceptance & Feedback & \\
& & & Communication & \\
\hline
\end{tabular}

The Table 1 shows a conceptual diagram illustrating the various stages in the life cycle of a construction project. Initiation and planning phases are the preliminary determinants of construction activities, where the concept of environmentally friendly and sustainable construction can be implemented.

The way in which the green concept of the life cycle of a construction project is different compared to the conventional concept in which each stage of the project life cycle is not related to each other. In the concept of green construction, every stage in project life cycle must create green value which then transferred to the next stage. In the end, the last green value in the project life cycle is an accumulation of the green values of the previous stages. This concept influences the management of a green project starting from planning to the operational phase of the building using integrated project delivery system to get maximum benefit [5].

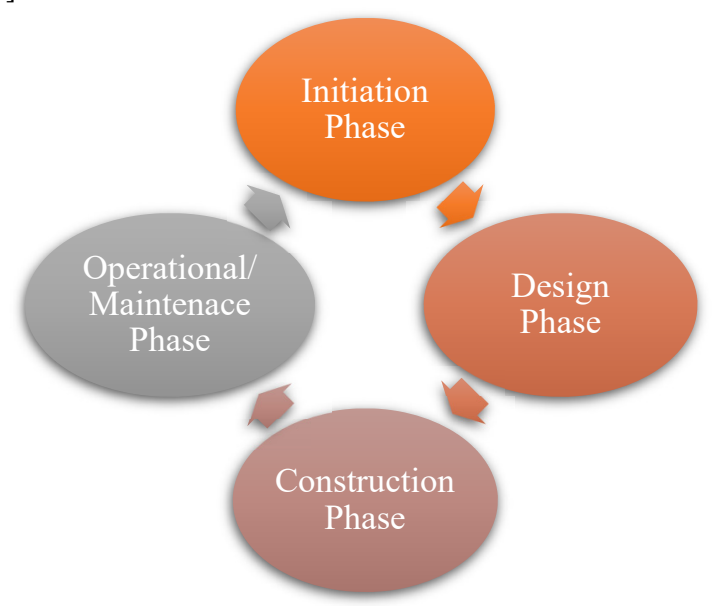

Fig. 2. Project life cycle by Oberlender [6]. 


\subsection{Initiation phase / project initiation}

Project Initiation is the initial phase of initiation or concept of the project. At this stage the owner must choose the process for design and construction. There are many process options, each with advantages and disadvantages. The selected process affects financing; selection of team members; and project cost, quality, and timeline. Although the process chosen is important, choosing qualified people is more important. A successful project is achieved by people working together with clear responsibilities. Outputs of the initiation stage include project characteristics or project documents containing project names, project budgets and project manager appointments, the document being used as a baseline by project managers to undertake the next project process [6].

\subsection{Phase design / project planning.}

The planning stage is the most important stage that takes a lot of time and personnel involved according to the size of the project. The planner consultant translates the concept desired by the owner into the picture and proposes the specifications of components and building materials. The ability of the planner depends heavily on the skill and ability to define the project scope of the owner / owner. Poor translation skills will have an effect on the start / source of project changes, repetitive work, schedule delays, and cost swelling. Green design consists of two main elements: life cycle assessment (LCA)and eco-conscious design (ECD) [7]. These two elements play an important role in minimising the overall negative environmental footprint caused by construction and keeping environmental considerations firmly for the execution [7]. The outputs of this stage include the structure and project team, detailed design drawings, job scopes, technical data, project schedules, work schedules, material / shopping schedules, procedures, and other details. This planning stage is key to the success of the next project stage [6].

\subsection{Construction phase / project execution}

The construction or execution stage is usually done simultaneously with the control stage. This stage is the stage of the implementation of the project, ranging from material spending, tools, and labour to the construction process that refers to the output of the planning stage. The contractor performs work based on planning approved by the owner and provides advices to owner and consultant if there is a plan picture and material type / component which is not suitable or not available in field. The construction phase is important because the quality of completed projects is highly dependent on construction work and management. The quality of construction depends on the completeness and quality of contract documents prepared by the designer and three other factors: workers with the necessary skills to produce jobs, field supervisors who have the ability to coordinate the various activities required to build projects in the field, and the quality of materials used for project development. Skilled workers and effective management of skilled workers are both required to achieve quality projects. Outputs from this stage include products (project work), control documents ranging from administrative control, quality control, labour control, material control, schedule control, to project financial controls, reports, meetings' result, test results and inspections and others that describe the implementation of the project. Everything in this phase should be well documented for the purposes of the next stage [6]. 


\subsection{Phase operational / maintenance / project closure / hand over}

The closing stage or project completion is the final stage of a project, this stage consists of handover and maintenance period, the handover is generally divided into two stages, the first stage after is construction work is completed and ready for use and then after the end of treatment. The beginning of the project closure begins when nearing the end of the project. This activity begins when the contractor requests a final examination of the work. Prior to the request, a checklist containing all items of work including those still in need of completion or correction is prepared. To check this list of jobs, field inspection personnel should carefully review the activities section including all daily inspection records for all work items, whichever item has been completed and which requires corrective action. Sometimes it is necessary to review all construction activities repeatedly before the work is declared complete and handover to owner. In the last field, inspection should involve representatives of the owners, contractors, and major design professionals (architects, as well as civil, electrical, and mechanical engineers, etc.) involved in the project. The project manager must schedule and conduct the final field inspection. The output of this stage is the final document containing all the control documents in the construction phase, the final drawing (as built drawing), and the operating manual and the handover report [6].

\subsection{Carbon emission in construction sector}

Buildings are large material users with high contained energy content. Embodied Energy corresponds to the energy consumed by all processes associated with the production of building materials and their components. This includes mining and manufacturing materials and equipment. Each building is a complex combination of many processed materials, each of which contributes to the total energy of the contained building. The realized energy is proportional to the level of processing required by the material. The more complex the material and the greater the amount of process required, the higher the amount of energy consumed. High contained energy levels imply a higher level of pollution at the end of production since energy consumption usually produces emissions. Concrete, aluminium and steel are among the materials with the highest contained energy content and they are also responsible for large quantities of $\mathrm{CO} 2$ emissions [8].

$\mathrm{CO} 2$ emission gas comes from energy released during the life cycle of the building starting from the production stage, construction phase, operational phase, and the demolition phase / the end of the building. Energy consumption produces $\mathrm{CO} 2$, which contributes to greenhouse gas emissions, so that contained energy is considered as an indicator of the overall environmental impact of building materials and systems [2].

Issues generated in the construction process include the ability to meet the needs of resources (materials, workers, equipment, methods) as the input component of the construction process, which is directly related to the output quality of buildings and waste, which is influenced by the activity of construction [5].

Carbon energy is the energy spent during the construction process taking into account the energy derived from the manufacturing, distribution / supply, transportation and equipment used during development work. Generally, this energy comes from the combustion (fossil), such as in factories and vehicles.

Embodied Carbon is calculated by $\mathrm{KgCO} 2 / \mathrm{Kg}$ unit of material or based on its functional unit using $\mathrm{kgCO} 2 / \mathrm{m} 3$ material or $\mathrm{kgCO} 2 / \mathrm{m} 2$ material, where each material has different energy values [9]. 


\subsection{Carbon emission relation with PLC}

Low carbon emission planning on the project life cycle (PLC) is generally integrated with the steps of decreased energy contained. Embodied carbon refers to energy consumed by $\mathrm{CO} 2$ consumed during product lifecycle duration whereas embodied energy is energy consumed during product lifecycle duration [3]. The following is the role of carbon emissions in the project life cycle (PLC):

\subsubsection{Initiation phase}

In this phase the carbon emission reduction relationship starts from the building concept desired by the owner such as the shape, type and function of the building. The owner has a very decisive role in the development activities where the role of owner as the owner of the land can provide direction and affirm the building concept should be based on low-carbon planning. This condition will be implemented and translated by the design and implementation in stages both in the design concept and the stage of construction implementation. Efforts to reduce carbon in this phase have no direct impact, but will have an impact on the design concept and the whole series of construction activities to the end of the building.

$>$ On projects in Indonesia where the government as the owner has issued a regulation on the concept of environmentally and sustainable development in which the emphasis is placed on efforts to optimize activities that produce carbon emissions. Through this rule every design and implementation of the project will refer to the concept of low carbon.

\subsubsection{Phase design}

Design or design phase is an implementation in the form of drawings and building specifications, where low carbon design can be done. In this phase the design of carbon reduction starts from the concept of building that implements green building where there is activity of design of tread space and form of building, low carbon material selection, and utilization of potential around the project area and prefer the green open space.

\subsubsection{Construction and handover phase}

$>$ In the construction phase is a direct contact phase in generating carbon emissions. Activities of construction phase include supply of materials, construction methods, use of tools and labour, waste management and cleaning of the remaining buildings and maintenance of the building before the building is handed over to the owner.

- The supply of materials for carbon emissions is calculated from the cradle to gate, cradle to site and cradle to handover processes, where there are carbon-producing activities both from within the material and the use of transportation during the process.

$>$ The method of construction implementation also affects the amount of carbon in which the construction method will determine the construction activity, the use of tools, as well as the optimization of construction materials and waste. One of the most frequently used construction methods of Lean Construction (LC) is a production-based approach to dealing with project issues, a new way to design and build capital facilities. Lean Construction Management has been a revolution in design in the manufacturing, supply and assembly industries. LC aims to produce lean systems by maximizing value and minimizing waste by certain techniques and applying them in a construction project completion process [10]. According to the theory of Lean Construction [11], Wastes are 
defined as an ineffective and efficient use of tools, materials, labour or working capital, which are much higher than would be required to realize the production of a construction project.

The use of tools and labour is the largest emitter of carbon emissions, where most equipment, especially heavy equipment vehicles, consume fossil-derived oil. The role of optimizing the use of heavy equipment will be crucial in reducing the amount of carbon emissions during the construction process, including the ability and expertise of the workforce in operating the equipment. Labour efficiency during construction activities also impacts carbon reduction, where carbon is calculated on the activities of workers during the project.

Waste management and residual cleaning of buildings and maintenance of buildings is the ultimate activity of the project life cycle. In this phase the amount of carbon is affected by the amount of waste produced either directly or indirectly. Direct carbonbased wastes generally originate from the combustion process of material waste at the project site while those indirectly come from the process of transporting solid waste discharges to landfill sites. Research shows that the construction industry generates large amounts of waste and more than $50 \%$ of the waste material is deposited in the final dump. Nearly $26 \%$ of landfill sites are occupied by construction waste $[12,13]$.

\section{Methodology}

This article uses a qualitative method approach by identifying and reviewing some of the literature that is associated with the reduction of carbon emissions in the construction project. This literature study aims to analyse and reveal the findings and views of previous researchers on carbon emissions and try to classify the content of the research into the Project Life Cycle (PLC) scope. Based on this view, the formulation of research problems related to carbon emission relation to PLC can be mapped more clearly.

This study uses secondary data sources in the form of a literature study taken from international journals with data collection techniques purposive sampling where data reduction conducted by focusing the search on precedents that have carbon emission research topic in the construction sector. Through these research topics can be known research parameters commonly used by researchers to propose efforts to reduce carbon emissions seen from PLC. The research journals are sampled as many as 20 pieces by emphasizing data analysis on parameters and methodologies used in the study area of research.

Journal data used has a range of five years of current research that is between 2013 to 2017. Data analysis method is done by mapping each of the research topics of the journal in tabular form. Furthermore, descriptive analysis conducted to create the interpretation of the analysis table. This article is still in the process of research so the development of literature is possibly conducted. Here are 10 literatures that have proximity to the steps or efforts to reduce carbon emissions in the construction sector, especially those associated with the project life cycle. The table results of research journal mapping on Carbon Emission Reduction Strategy reviewed in Project Life Cycle (PLC) as below. 
Table 2. Research on carbon emission decrease strategies reviewed in the project life cycle (PLC).

\begin{tabular}{|c|c|c|c|c|c|c|c|c|c|}
\hline \multirow[b]{2}{*}{ References } & \multirow[b]{2}{*}{ Year } & \multirow[b]{2}{*}{ Location } & \multirow[b]{2}{*}{$\begin{array}{c}\text { Type of } \\
\text { Research / } \\
\text { Analysis }\end{array}$} & \multirow[b]{2}{*}{$\begin{array}{c}\text { Type of } \\
\text { Construc } \\
\text { tion }\end{array}$} & \multirow[b]{2}{*}{$\begin{array}{c}\text { Para- } \\
\text { meter } \\
\text { Studied }\end{array}$} & \multicolumn{3}{|c|}{ Life Cycle Project } & \multirow[b]{2}{*}{$\begin{array}{l}\text { Case } \\
\text { Study }\end{array}$} \\
\hline & & & & & & $\begin{array}{l}\text { Initia- } \\
\text { tion }\end{array}$ & $\begin{array}{l}\text { De- } \\
\text { sign }\end{array}$ & $\begin{array}{l}\text { Cons } \\
\text { truc- } \\
\text { tion }\end{array}$ & \\
\hline $\begin{array}{l}\text { Hermawan } \\
\text { et al. }\end{array}$ & 2013 & $\begin{array}{c}\text { Indonesi } \\
\mathrm{a} \\
\end{array}$ & LCA & Building & $\mathrm{CO}_{2}$ & & $\mathrm{x}$ & $\mathrm{x}$ & $\begin{array}{l}\text { Building } \\
\text { Material }\end{array}$ \\
\hline $\begin{array}{l}\text { Malmqvist } \\
\text { et al. }\end{array}$ & 2014 & UE & $\begin{array}{c}\text { Comparing } \\
\text { study / } \\
\text { literary } \\
\text { study }\end{array}$ & $\begin{array}{l}\text { Build \& } \\
\text { Resident } \\
\quad \text { ial }\end{array}$ & $\begin{array}{l}\text { Energy } \\
, \mathrm{CO}_{2}\end{array}$ & $\mathrm{x}$ & $\mathrm{x}$ & $\mathrm{x}$ & $\begin{array}{l}\text { Building } \\
\text { Construc } \\
\text { tion }\end{array}$ \\
\hline $\begin{array}{l}\text { Giesekam } \\
\text { et al. }\end{array}$ & 2014 & UK & LCA & Building & $\mathrm{CO}_{2}$ & $\mathrm{x}$ & $\mathrm{x}$ & $\mathrm{x}$ & $\begin{array}{l}\text { Building } \\
\text { Material }\end{array}$ \\
\hline $\begin{array}{l}\text { Efstratios } \\
\text { and Alice }\end{array}$ & 2014 & UK & $\begin{array}{l}\text { Quasy- } \\
\text { experiment } \\
\text { al }\end{array}$ & Building & $\begin{array}{l}\text { Energy } \\
, \mathrm{CO}_{2}\end{array}$ & $\mathrm{x}$ & $\mathrm{x}$ & $\mathrm{x}$ & $\begin{array}{c}\text { Building } \\
\text { Construc } \\
\text { tion }\end{array}$ \\
\hline $\begin{array}{l}\text { Krantz et } \\
\text { al. }\end{array}$ & 2015 & Sweden & $\begin{array}{c}\text { LCA - } \\
\text { Experimen } \\
\text { tal, } \\
\text { modelling } \\
\end{array}$ & $\begin{array}{l}\text { Infrastru } \\
\text { cture }\end{array}$ & $\begin{array}{l}\text { Energy } \\
, \mathrm{CO}_{2}\end{array}$ & & $\mathrm{x}$ & $\mathrm{x}$ & $\begin{array}{l}\text { Bridge } \\
\text { Construc } \\
\text { tion }\end{array}$ \\
\hline $\begin{array}{l}\text { Poyry et } \\
\text { al. }\end{array}$ & 2015 & Finland & $\begin{array}{c}\text { LCA I/O } \\
\text { data, case } \\
\text { study }\end{array}$ & $\begin{array}{l}\text { Resident } \\
\text { ial }\end{array}$ & $\mathrm{CO}_{2}$ & & & $\mathrm{x}$ & $\begin{array}{c}\text { Building } \\
\text { Construc } \\
\text { tion }\end{array}$ \\
\hline Dixit et al. & 2015 & USA & $\begin{array}{c}\text { Comparing } \\
\text { study / } \\
\text { literary } \\
\text { study }\end{array}$ & Building & $\mathrm{CO}_{2}$ & & $\mathrm{x}$ & $\mathrm{x}$ & $\begin{array}{l}\text { Building } \\
\text { Construc } \\
\text { tion }\end{array}$ \\
\hline Yu et al. & 2016 & Australia & $\begin{array}{c}\text { EA / } \\
\text { Economic } \\
\text { I/O data }\end{array}$ & $\begin{array}{c}\text { Build \& } \\
\text { Resident } \\
\text { ial } \\
\end{array}$ & $\mathrm{CO}_{2}$ & & & $\mathrm{x}$ & $\begin{array}{l}\text { Building } \\
\text { Material }\end{array}$ \\
\hline $\begin{array}{c}\text { Othman } \\
\text { and } \\
\text { Mohamme } \\
\text { d }\end{array}$ & 2016 & Malaysia & $\begin{array}{c}\text { Comparing } \\
\text { study / } \\
\text { literary } \\
\text { study } \\
\end{array}$ & Building & $\mathrm{CO}_{2}$ & & $\mathrm{x}$ & & $\begin{array}{l}\text { Building } \\
\text { Construc } \\
\text { tion }\end{array}$ \\
\hline $\begin{array}{l}\text { Rasmussen } \\
\text { et al. }\end{array}$ & 2017 & UE & $\begin{array}{c}\text { Comparing } \\
\text { study / } \\
\text { literary } \\
\text { study } \\
\end{array}$ & Building & $\begin{array}{l}\text { Energy } \\
, \mathrm{CO}_{2}\end{array}$ & $\mathrm{x}$ & $\mathrm{x}$ & $\mathrm{x}$ & $\begin{array}{l}\text { Building } \\
\text { Construc } \\
\text { tion }\end{array}$ \\
\hline
\end{tabular}

\section{Result and discussion}

Table 2 illustrates some of the literature based on the carbon emission reduction relationship to activity on the project life cycle (PLC). From 10 pieces of literatures there are 4 researchers analysing the decrease of carbon emission based on comparative study or literature study approach [14-17]. There are 2 literatures analysing using the LCA approach [18-19], while [20] uses the LCA combination approach with Input-Output Data to assess carbon emissions against materials used in components residential building structures in Finland. [21] uses the LCA-Experimental approach which produces models on bridge structures, where this model takes into account carbon emission reductions in the construction process. The questionnaire method combined with experimental simulations was used [22] in searching for steps to reduce the role of contained energy and carbon based on building life cycle information. Meanwhile, [23] uses an Input-Output Data-based economic analysis to calculate the carbon footprint of the construction sector in Australia.

From 10 literatures, only 4 literatures have some discussion of carbon sequestration in the initiation phase $[14,17,19]$. While in the design phase only 2 literatures do not touch the efforts of carbon reduction [16,20]. In the construction phase almost all literature provides 
responses and recommendations for emissions reduction except in [16] literature. In this literature analysis, there are 3 types of case studies, namely case study on construction building with 6 cases, building material 3 cases and 1 case in bridge building (infrastructure).

As for general efforts suggested by each researcher as follow:

\subsection{Initiation Phase}

There is a need for stakeholder understanding to prioritize environmental considerations in terms of carbon degradation by applying regulations applicable to each type of construction activity $[14,19]$.

$>$ The role of the government in providing stakeholder understanding of the importance of low-emission buildings and establishing a benchmark or reference of low-carbon building models that are in line with standards so that communities can see and compare the benefits of low-carbon planning concepts [19, 22].

> Stakeholders are required to follow and use environmentally sound building standards which have been established by government and international institutions before planning the building [17, 22].

\subsection{Phase design}

$>$ Design is more emphasized on the concept of low carbon design with attention to optimizing the structure / building element.

$>$ The choice of low carbon building materials is prioritised

$>$ The design also takes into account the process of ease of disassembly

$>$ The design should also consider the concept of renewable energy usage

$>$ A deeper understanding of LCA will help the designer in designing low carbon design concepts especially on the use of cement, steel and ceramic materials.

$>$ The highest use of energy and carbon emitters occurs at this operational stage should be a concern for planners to be more innovative in generating designs [16].

\subsection{Construction and handover phase}

$>$ Optimisation of the supply chain should be done to shorten the flow of material and equipment distribution

$>$ Machine optimisation and increased operator expertise will influence emissions reduction

$>$ The choice of construction method will affect the efficiency of time and cost as well as material so that the waste generated will also be less.

$>$ The use of eco-labelled materials in every building component also has an impact on carbon reduction

$>$ Optimisation of energy, electricity, gas \& water and material utilization in every construction operational activity

$>$ Implement planned waste management through the concept of reduce, reuse and recycle.

$>$ Utilization of new technologies and renewable energy will help in reducing the amount of carbon emissions [23].

$>$ Engineering of building structures using green cement and the utilization of wood materials will further reduce carbon emissions [20]. 


\section{Conclusion}

Activity in the construction sector is one of the energy users and contributor of the world's carbon emissions that greatly affect the environmental conditions and has an impact on global warming. Efforts to reduce carbon emissions, which is very important for environmental sustainability, is maintained. The carbon emissions reduction measures in the construction life cycle start from the initiation stage where the project owner has great authority in determining the whole series of construction activities. By putting forward the concept of low carbon in the initiation phase it will continue on low carbon design and low carbon construction. Therefore, the concept of low carbon will be developed on low carbon operational, low carbon dismantling and recycling following the life cycle of the building. In addition, current issues on the taxation of carbon in each sector including construction will emphasise the stakeholders to prefer the concept of low carbon development as well as sustainable environmental insight.

\section{References}

1. M.K. Dixit, C.H. Clup, J.L.F. Solis, Renewable and Sustainable Energy Reviews, 21, pp. 153- 164 (2013)

2. NASA's Goddard Institute for Space Studies., Global Temperature, (2017)

3. J. Goggins, IBCI Building Control Conference | Athlone, 28-29 March 2012, Engineering \& Informatics, NUI Galway Ryan Institute for Environment, Marine \& Energy Research. (2012)

4. W.R. Ducan, Project Management Institute, four Campus Boulevard, Newtown Square, pp. 19073-3299 (1996)

5. W.I. Ervianto, Disertasi, ITB, Bandung. (2015)

6. D. Oberlender, Project Management for Engineering and Construction, 2, (2000)

7. M. A. Wibowo, N. U. Handayani, A. Mustikasari, A. Nurdiana, M.N. Soleh, A Literature Review, (2018)

8. A.B. Larriba, O. Wolf, Institute for Prospective Technological Studies, JRC Europe Commission, (2010)

9. G.P. Hammond, C.L. Jones, Proceedings of the Institution of Civil Engineers Energy, 161, pp. 87-98 (2008)

10. Lean Construction Institute, "What is lean construction?". Retrieved 13 February 2013 from http://www.leanconstruction.org. (2012)

11. L. Koskela, Technical Report, 72, Stanford University. (1992)

12. B.G. Hwang, Z.B. Yeo, Journal of Engineering, 18 (4), pp. 394-406 (2011)

13. A.G Bossink, H.J.H. Journal of Construction Engineering and Management, 122(1), pp. 55-60 (1996)

14. T. Malmqvist, H. Birgisdottir, A.H. Wiberg, A. Moncaster, N. Brown, V. John, A. Passer, J. Potting, E. Soulti, Analyses of the IEA Annex 57 Case Studies World SB4, Bancelona. (2014)

15. M.K. Dixit, C.H. Clup, J.L.F. Solis, S. Lavy, Emerald Group Publishing Limited 02632772, 34 (3/4), pp. 247-259 (2015)

16. M. Othman, A.F. Mohamed, International Jurnal of Malay World and Civilisation, 4 (Special Issue 1), pp. 95-100 (2016) 
17. F.N. Rasmussen, T. Malmqvist, A. Moncaster, A.H. Wiberg, H. Birgisdóttir, Energy and Buildings, (2017)

18. Hermawan, P.F. Marzuki, M. Abduh, R. Driejana, Konferensi Nasional Teknik Sipil, 7, pp. K-47-52 (2013)

19. J. Giesekam, J. R. Barrett, P. Taylor, A. Owen, Energy and Buildings, (2014)

20. A. Pöyrya, A. Säynäjokia, J. Heinonenc, J.M. Junnonenb, S. Junnila, Procedia Economics and Finance, 21, pp. 355 - 365 (2015)

21. J. Krantz, J. Larsson, W. Lu, Y. Olofsson, Buildings 2015, 5, p. 1156-1170 (2015)

22. G. Efstratios, M. Alice, UK case study World SB4, Bancelona. (2014)

23. M. Yu, T. Wiedmann, R. Crawford, C. Tait, Procedia Engineering, 180, pp. $211-220$ (2016) 